\title{
Bahaya Penularan Covid-19 di Gua dan Upaya Pencegahannya
}

\section{The Pitfall of Covid-19 Transmision in Caves and Its Prevention}

\author{
Isma Dwi Kurniawan ${ }^{1,4 *}$, Cahyo Rahmadi ${ }^{2,4}$, Rasyid Wisnuaji ${ }^{3,4}$ \\ ${ }^{1}$ Jurusan Biologi, UIN Sunan Gunung Djati Bandung. ${ }^{2}$ Museum Zoologicum Bogoriense, Lembaga Ilmu \\ Pengetahuan Indonesia (LIPI). ${ }^{3}$ Jurusan Ekonomi Pembangunan, Universitas Nahdlatul Ulama Al- \\ Ghozali Cilacap. ${ }^{4}$ Indonesian Speleological Society (ISS). *Corespondent email: \\ ismadwikurniawan@uinsgd.ac.id
}

Received: 13 July 2020 | Accepted: 21 October 2020 | Published: 30 Desember 2020

\begin{abstract}
Abstrak. Gua memiliki potensi besar sebagai tempat penularan Covid-19. Aktivitas penelusuran gua di masa pandemi berpotensi meningkatkan dan memperluas penyebaran Covid-19. Artikel ini bertujuan untuk memberikan informasi mengenai potensi bahaya aktivitas penelusuran gua di masa pandemi Covid-19 dan upaya-upaya yang dapat dilakukan untuk mencegahnya. Data diperoleh melalui metode Systematic Literature Review (SLR). Lingkungan gua memiliki karakter tertutup, tidak terdapat sinar matahari, minim ventilasi dan sirkulasi udara, suhu stabil dan kelembapan tinggi sehingga sangat ideal untuk terjadinya proses penularan Covid-19 antar manusia. Selain itu, gua juga menjadi habitat bagi kelelawar (Chiroptera) yang ternyata memiliki kemungkinan tertular Covid-19 dari manusia. Rute transmisi virus dari manusia ke kelelawar dan ditularkan kembali ke manusia dikhawatirkan terjadi. Pencegahan penyebaran Covid-19 di lingkungan gua dapat dilakukan di antaranya adalah dengan cara menunda kunjungan ke gua apabila kepentingan tidak mendesak, menggunakan peralatan SOP penelusuran gua, menerapkan protokol kesehatan dengan ketat, pembatasan jumlah penelusur dan durasi eksplorasi, tidak kontak langsung dengan kelelawar, dan menghindari lorong-lorong gua yang menjadi habitat kelelawar.

Kata kunci: Covid-19, SARS-CoV-2, transmisi, gua, kelelawar

Abstract. Caves are an ideal place for Covid-19 transmission. Caves exploration in the pandemic period could increase and extend transmission risk of Covid-19.This article contains information regarding the risk of caves exploration during Covid-19 pandemic and prevention efforts that can be taken to reduce the risk. Data were gained through systematic literature review (SLR). Caves are enclosed environment without sunlight, lack of air circulation, stable temperature, and saturated humidity which are suitable for Covid-19 transmision among people. In the other hands, caves are also inhabited by bats (Chiroptera) which are susceptible to SARS-CoV-2. The route of SARS-CoV-2 transmision from infected humans to bats and back to humans is concerned. Covid-19 transmission in caves can be prevented through several ways including postphoning cave exploration during pandemic, bearing standard operating procedure specific for cave exploration, practicing health safety protocols, limiting the numbers of visitor and exploration duration, and avoiding direct and indirect contact with bats.

Keyword: Covid-19, SARS-CoV-2, transmission, caves, bats
\end{abstract}

\section{PENDAHULUAN}

Pandemi Covid-19 yang saat ini sedang melanda dunia telah berdampak luas hampir ke seluruh bidang kehidupan manusia. Penyakit pernafasan mematikan yang disebabkan oleh virus SARS-CoV-2 ini memiliki daya penularan yang sangat tinggi dan telah menginfeksi jutaan orang di hampir seluruh negara di dunia (Shang et al., 2020; WHO, 2020; Zheng, 2020). Hingga saat ini, belum terdapat obat maupun vaksin khusus untuk penyakit ini sehingga langkah efektif pencegahan infeksi yang dapat dilakukan adalah melalui pemberlakuan protokol kesehatan yang ketat (Dhama et al., 2020; Sun et al., 2020; Tu et al., 2020). Selain itu, masyarakat juga 
dihimbau untuk menunda kunjungan ke tempat-tempat yang berpotensi sebagai pusat penyebaran virus.

Gua menjadi salah satu tempat yang berpotensi besar dalam penyebaran Covid-19. Kondisi khas lingkungan gua yang tertutup, gelap, lembap, dan minim sirkulasi udara sangat mendukung proses transmisi virus dari satu manusia ke manusia lainnya (Chan et al., 2011; Wu et al., 2020). Selain itu, terdapat juga potensi terjadinya penularan virus SARS-CoV-2 dari manusia ke fauna yang hidup di dalam gua (Nuñez et al., 2020). Aktivitas penelusuran gua di masa pandemi sangat berisiko memunculkan kluster-kluster baru penyebaran Covid-19. Mekanisme transmisi virus yang jauh lebih kompleks yaitu dari manusia ke fauna lalu ditularkan kembali ke manusia juga dimungkinkan terjadi (Oreshkova et al., 2020; Sharun et al., 2020).

Aktivitas kunjungan ke gua sangat sering dilakukan oleh masyarakat di Indonesia. Masyarakat mengunjungi gua untuk tujuan yang beragam, di antaranya adalah untuk menggelar kegiatan adat, budaya, dan religi, bertapa, menambang, berburu, berpetualang, berwisata dan melakukan penelitian (Kurniawan dan Rahmadi, 2019). Pada beberapa jenis kegiatan tersebut, seringkali melibatkan orang dalam jumlah yang banyak sebagai contoh kegiatan wisata dan religi. Beberapa kegiatan lainnya seperti penelitian, penambangan, dan perburuan mengharuskan kontak dengan fauna penghuni gua baik secara langsung maupun tidak langsung.

Kombinasi karakter khas lingkungan gua dan beragamnya aktivitas kunjungan manusia ke gua memunculkan kekhawatiran akan terjadinya penularan Covid-19 yang masif di dalam gua. Artikel ini bertujuan untuk memberikan informasi mengenai risiko bahaya penelusuran gua di masa pandemi Covid-19 dan upaya-upaya yang dapat dilakukan untuk mencegah terjadinya penyebaran Covid-19 melalui perantara lingkungan dan fauna penghuni gua. Informasi tersebut diharapkan dapat menjadi bahan pertimbangan bagi seluruh masyarakat untuk lebih peduli dan berhati-hati apabila hendak melakukan aktivitas penelusuran atau kunjungan ke gua di masa pandemi Covid-19.

\section{METODE}

Tinjauan ini menggunakan pendekatan observasional deskriptif dengan metode Systematic literature review (SLR). SLR dilakukan untuk mengidentifikasi, mengkaji, mengevaluasi, dan menafsirkan penelitian-penelitian yang tersedia berkaitan dengan topik fenomena yang dipelajari (Triandini et al., 2019). Sumber pustaka ditelusur secara daring melalui situs-situs yang memuat database publikasi ilmiah seperti Google Scholar dan Researchgate dengan kata-kata kunci yang berkaitan dengan pandemi Covid-19, karakteristik SARS-CoV-2 sebagai virus penyebab penyakit Covid-19, karakter khas lingkungan gua yang mendukung penyebaran SARS-CoV-2, dan potensi penularan SARS-CoV-2 dari manusia ke fauna. Pustaka yang ditelaah adalah terbitan 10 tahun terakhir yaitu dari tahun 2011-2020. Sumber pustaka berasal dari jurnal internasional (35 artikel), prosiding internasional (1 artikel), buku (2 buah), laporan dan rekomendasi para ahli (2 artikel), dan website bereputasi (2 artikel). 


\section{HASIL DAN PEMBAHASAN}

\section{Karakter lingkungan gua yang mendukung penularan Covid-19}

Proses penularan virus tidak dapat dipisahkan dari kondisi lingkungan tempat virus berada. Meskipun virus tidak dapat memperbanyak diri di luar tubuh makhluk hidup, akan tetapi kondisi lingkungan sangat mempengaruhi keberhasilan transmisi virus ke inangnya. Beberapa penelitian menunjukkan bahwa kondisi lingkungan seperti suhu dan kelembapan udara sangat berpengaruh terhadap viabilitas atau ketahanan virus di lingkungan sehingga secara tidak langsung ikut menentukan keberhasilan penularan (Chan et al., 2011; Wu et al., 2020). Hal ini juga berlaku untuk SARS-CoV-2 yang menyebabkan pandemi Covid-19.

Gua memiliki karakter lingkungan yang khas yaitu di antaranya tertutup, gelap, lembap, dan pengap (Kurniawan dan Rahmadi, 2019). Kondisi lingkungan yang demikian ternyata sangat mendukung proses penularan Covid-19. Banyak kasus penularan Covid-19 dilaporkan terjadi di ruangan tertutup dan minim ventilasi. Tidak adanya sinar matahari dan sirkulasi udara menjadi alasan mengapa potensi penularan di gua dapat lebih tinggi. Beberapa sumber menjelaskan bahwa sinar ultraviolet (UV) yang terkandung dalam sinar matahari dapat menurunkan viabilitas mikroba termasuk virus (Hobday dan Dancer, 2013). Selain itu, panas yang dibawa sinar matahari dan adanya sirkulasi udara dapat mempercepat pengeringan droplet yang menjadi media penularan utama SARS-CoV-2 sehingga virus akan lebih cepat mati (Ratnesar-Shumate et al., 2020).

Mempertimbangkan kondisi lingkungan khas gua yang mendukung viabilitas virus di lingkungan, maka kegiatan penelusuran atau kunjungan manusia yang terinfeksi Covid-19 ke gua sangat berbahaya. Pada kasus gua-gua yang sering dikunjungi semisal gua wisata, penularan dapat terjadi secara kontinu meskipun orang positif yang menjadi sumber penularan sudah tidak berada di gua tersebut. Hal ini terjadi karena virus SARS-CoV-2 dapat bertahan di udara dan permukaan benda di dalam gua dalam waktu lama. SARS-CoV-2 diketahui dapat bertahan di udara hingga 3 jam, sedangkan viabilitas virus ini di permukaan benda berkisar 4-72 jam bergantung dari jenis bahan. Stabilitas SARS-CoV-2 paling tinggi terjadi di permukaan plastik, diikuti stainless, kardus, dan tembaga (Doremalen et al., 2020; Zhang, 2020). Risiko paparan tidak hanya dapat terjadi melalui kontak dengan virus yang bertahan di lingkungan gua tetapi juga kontak langsung dengan orang yang terinfeksi dan atau peralatan penelusuran gua yang terkontaminasi virus. Penelusuran gua terutama gua-gua dengan lorong vertikal dan kompleks seringkali membutuhkan teknik khusus yang menuntut kontak langsung antar anggota penelusur untuk saling membantu selama penelusuran. Selain itu, beberapa peralatan juga seringkali digunakan secara bergantian sehingga berpotensi menjadi media penularan virus.

\section{Transmisi virus dari manusia ke kelelawar penghuni gua}

Virus SARS-CoV-2 memiliki daya infeksi yang kuat. Dibandingkan dengan pendahulunya yaitu SARS-CoV yang menyebabkan penyakit SARS, SARS-CoV-2 memiliki afinitas terhadap sel inang yang jauh lebih tinggi (Shang et al., 2020). Selain itu, SARS-CoV-2 juga tergolong kelompok virus RNA yang dikenal cepat mengalami mutasi (Kim et al., 2020; Tang et al., 2020). Salah satu kekhawatiran dari kemampuan SARS-CoV-2 adalah potensi infeksi ke spesies lain selain manusia. Para peneliti memprediksi bahwa virus ini memiliki kemampuan untuk menginfeksi hewan terutama anggota Kelas Mamalia yang memiliki kedekatan genetik dengan manusia. Hingga saat ini, bukti ilmiah terkait hal tersebut telah dilaporkan di antaranya terjadi 
pada anjing (Famili: Canidae), kucing dan harimau (Felidae), dan cerpelai (Mustelidae) yang terbukti positif SARS-CoV-2 (Kiros et al., 2020; Kumar et al., 2020; ProMed, 2020; Tiwari et al., 2020). Penelitian terkait hal tersebut masih terus dilakukan dan informasi akan terus berkembang.

Salah satu spesies fauna yang diduga berpotensi besar tertular SARS-CoV-2 adalah kelelawar. Baru-baru ini, kelompok ahli dan peneliti kelelawar yang tergabung dalam IUCN SSC Bat Specialist Group (BSG) menyebutkan bahwa potensi penularan Covid-19 ke kelelawar memungkinkan terjadi (Nuñez et al., 2020). Terdapat beberapa alasan mengapa kelelawar berpotensi tertular SARS-CoV-2 di antaranya adalah karena kelelawar memang merupakan inang alami bagi virus korona (Wong et al., 2019). Banyak penelitian menunjukkan bahwa virus korona sangat umum dijumpai di kelelawar (Valitutto et al., 2020). Dari 4 genus virus korona, 2 di antaranya yaitu kelompok alfa dan beta-coronavirus banyak hidup di kelelawar. SARS-CoV-2 yang menyebabkan penyakit Covid-19 sendiri merupakan anggota dari beta-coronavirus yang diduga berasal dari kelelawar sebelum akhirnya menular ke manusia (Zhou et al., 2020). Dugaan ini muncul karena SARS-CoV-2 memiliki kemiripan genetik yang tinggi dengan virus korona yang dikoleksi dari kelelawar Genus Rhinolophus (Tang et al., 2020; Zhou et al., 2020). Selain itu, SARS-CoV-2 juga berasal dari genus yang sama dengan virus penyebab penyakit SARS dan MERS yang semuanya telah diketahui bersifat zoonosis dan berasal dari kelelawar (Han et al., 2015; Ranjan et al., 2016). SARS-CoV ditularkan dari kelelawar secara tidak langsung melalui inang antara (intermediate reservoir) luwak sawit (Paguma larvata), sedangkan MERS-CoV ditularkan melalui inang antara unta (Allocati et al., 2016; Helmy et al., 2020). SARS-CoV-2 juga diduga ditularkan melalui inang antara, akan tetapi hingga saat ini belum diketahui secara pasti spesies yang menjadi inang antara tersebut. Trenggiling (Manis javanica) menjadi salah satu fauna yang diduga kuat sebagai inang antara tersebut karena adanya kemiripan receptor binding domain (RBD) yang tinggi antara virus korona yang ditemukan di trenggiling dengan SARS-CoV-2 (Andersen et al., 2020; Zhang et al., 2020b) (Gambar 1).



Gambar 1. Rute penularan SARS-CoV, MERS-CoV, dan SARS-CoV-2 dari kelelawar ke manusia (Helmy et al., 2020). 
Kurniawan et al., 2020. Bahaya penularan Covid-19 di Gua....

Penularan virus SARS-CoV-2 dari manusia ke kelelawar sangat mungkin terjadi di dalam gua sebab kelelawar merupakan kelompok fauna yang sangat umum dijumpai di ekosistem gua. Karakter lingkungan gua yang stabil, gelap, dan lembap merupakan tempat yang sesuai bagi kelelawar untuk melindungi diri dari fluktuasi lingkungan dan ancaman predator (Furey dan Racey, 2016). Pada siang hari, mereka biasanya dijumpai bertengger di atap gua. Kunjungan manusia yang terinfeksi Covid-19 ke gua tidak hanya berpotensi menularkan virus ke sesama manusia, akan tetapi juga ke kelelawar. Percikan/droplet infeksius yang dikeluarkan manusia dapat bertahan di udara dan permukaan benda di dalam gua yang selanjutnya dapat menginfeksi kelelawar. Potensi penularan akan meningkat ketika kunjungan ke gua bertujuan untuk hal-hal yang bersinggungan langsung dengan kelelawar, sebagai contoh pada kasus penangkapan kelelawar baik untuk keperluan konsumsi maupun penelitian. Berada pada jarak terlalu dekat dengan kelelawar dan kemungkinan adanya kontaminasi virus pada tangan dan peralatan yang digunakan dalam penangkapan kelelawar dapat menjadi media penularan virus dari manusia ke kelelawar (Nuñez et al., 2020).

Pertanyaan yang muncul adalah kenapa penularan Covid-19 ke kelelawar menjadi hal serius yang harus diantisipasi?. Selain dapat membahayakan kelestarian hidup kelelawar yang berperan penting sebagai penyedia jasa lingkungan bagi manusia, kemungkinan terjadinya penularan balik dari kelelawar ke manusia adalah jawabannya. Transmisi balik SARS-CoV-2 dari hewan ke manusia telah dilaporkan terjadi di sebuah peternakan cerpelai di Belanda. Beberapa peternak diketahui terinfeksi SARS-CoV-2 dari cerpelai (Mustela lutreola) yang sebelumnya telah terinfeksi dari manusia (ProMed, 2020; Oreshkova et al., 2020; Sharun et al., 2020). Hal ini menjadi bukti bahwa penularan balik virus dari hewan ke manusia sangat mungkin terjadi. Meskipun hingga saat ini bukti adanya penularan Covid-19 dari kelelawar ke manusia belum tersedia, akan tetapi melihat sejarah asal mula dan karakteristik SARS-CoV-2 yang sangat infeksius maka kewaspadaan sudah seharusnya ditingkatkan.

Kelelawar yang terinfeksi virus SARS-CoV-2 dapat menjadi agen penular yang berbahaya bagi manusia. Kelelawar memiliki karakteristik hidup berkumpul dan jarak fisik antara satu individu dengan lainnya dalam suatu koloni sangat dekat. Kelelawar tentu tidak dapat diatur dengan protokol kesehatan selayaknya manusia. Apabila satu individu saja tertular, maka besar kemungkinan virus akan menyebar dengan cepat ke seluruh anggota koloni (Balboni et al., 2012).

Selain itu, kelelawar yang hidup di dalam gua tidak setiap saat berada di dalam gua. Pada malam hari, mereka akan pergi ke luar gua untuk mencari makan (Kurniawan dan Rahmadi, 2019). Maknanya, potensi penularan balik ke manusia tidak hanya ada di dalam gua tetapi meluas ke lingkungan luar gua. Satu lagi karakter kelelawar yang mendukung penularan virus adalah bahwa fauna ini sangat mudah mengeluarkan percikan lendir. Mayoritas kelelawar penghuni gua termasuk dalam kelompok pemakan serangga (Microchiroptera) yang menggunakan pantulan gelombang suara (ekolokasi) untuk orientasi. Ketika kelelawar melakukan ekolokasi, secara tidak langsung mereka mengeluarkan percikan lendir dari mulut maupun hidung ke lingkungan sekitar mereka berada. Hal ini berarti penularan balik dapat terjadi meskipun manusia tidak kontak langsung dengan kelelawar, akan tetapi juga secara tidak langsung melalui percikan infeksius yang ditinggalkan kelelawar. 


\section{Upaya pencegahan transmisi Covid-19 di Gua}

Menunda kunjungan ke gua sampai kondisi pandemi ini berakhir atau hingga ditemukannya vaksin spesifik untuk SARS-COV-2 adalah cara terbaik mencegah penularan Covid-19 di gua. Sebelum memutuskan untuk mengunjungi gua, hendaknya setiap orang menilai seberapa penting tujuan dari kunjungan yang akan dilakukan. Apabila kepentingan ke gua tidak mendesak semisal hanya untuk kepentingan hobi dan refreshing, maka sebisa mungkin menundanya hingga situasi membaik. Akan tetapi, sepenuhnya melarang kunjungan ke gua juga sulit dilakukan karena beberapa alasan. Sebagai contoh adalah kasus gua wisata yang menjadi tempat banyak masyarakat mencari nafkah. Apabila gua wisata ditutup berkepanjangan, maka roda perekonomian akan terhenti dan banyak masyarakat akan terdampak. Oleh karena itu, rekomendasi mengenai tata cara penelusuran gua di masa pandemi sangat diperlukan guna menurunkan risiko penularan Covid-19 selama kunjungan ke gua.

Aktivitas penelusuran gua di masa pandemi memang sangat berisiko menularkan dan tertular Covid-19. Akan tetapi, beberapa hal dapat dilakukan untuk meminimalisir risiko paparan tersebut. Hal terpenting yang dapat dilakukan adalah dengan menerapkan protokol kesehatan secara baik dan benar ketika berkunjung ke gua, apapun tujuan kunjungannya.

Kegiatan wisata gua perlu mendapatkan perhatian khusus karena umumnya melibatkan banyak orang dan seringkali tidak menggunakan peralatan penelusuran gua yang sesuai dengan standard operating procedure (SOP). Ketika pengelola memutuskan untuk membuka objek gua wisata di masa pandemi maka pengelola harus memberlakukan protokol kesehatan yang ketat di lokasi gua wisata. Sarana dan prasarana yang mendukung implementasi protokol kesehatan harus disediakan di depan pintu masuk gua sebagai contoh termometer, hand sanitizer dan tempat cuci tangan lengkap dengan sabun dan air mengalir. Penggunaan masker, sarung tangan, pakaian yang menutup tangan dan kaki, serta sepatu selama kunjungan ke gua wisata sangat direkomendasikan oleh International Show Caves Association (Durán-Valsero et al., 2020). Salah satu hal penting lainnya adalah pengelola harus memastikan bahwa pengunjung tidak menyentuh benda apapun, meludah, dan meminimalisir berbicara di dalam gua karena aktivitas tersebut dapat menyebarkan droplet infeksius ke lingkungan gua.

Kontaminasi virus SARS-CoV-2 ke lingkungan gua harus dicegah secara maksimal. Hal ini penting sebab sterilisasi virus dengan penyemprotan desinfektan secara masif di dalam lingkungan gua tidak dapat dilakukan karena langkah ini dapat membunuh biota yang hidup di dalam gua. Beberapa penelitian menunjukkan bahwa disinfektan yang digunakan untuk mencegah penyebaran Covid-19 mengandung senyawa toksik seperti klorin dan alkohol yang dapat membunuh biota baik yang hidup di lingkungan akuatik maupun terestrial (Iyiola et al., 2020; Nabi et al., 2020; Zhang et al., 2020a). Terdapat beberapa jenis senyawa disinfektan yang direkombinasikan spesifik untuk lingkungan gua yaitu etanol 70\%, asam organik (asam laktat dan asam sitrat), hidrogen peroksida (3-4\%), dan hipoklorit. Senyawa-senyawa tersebut terbukti efektif membunuh SARS-CoV-2 dalam waktu kurang dari 5 menit dan relatif aman bagi ekosistem gua. Akan tetapi, senyawa tersebut hanya boleh diaplikasikan pada permukaan infrastruktur di gua wisata yang dibuat dari bahan tidak berpori seperti plastik, logam, dan kaca bukan disemprotkan ke seluruh bagian lingkungan gua (Barton, 2020). 
Jumlah pengunjung dan durasi eksplorasi di gua wisata harus dibatasi dengan tegas agar tidak terjadi kerumunan. Pembuatan tanda jaga jarak dapat dilakukan di lokasi-lokasi yang seringkali menjadi pusat kerumunan semisal di tempat pembelian tiket dan pintu masuk gua. Jarak individu antar wisatawan atau antar kelompok wisatawan selama kunjungan diatur setidaknya 1.5-2 m. Stasiun-stasiun pemberhentian dapat ditentukan di beberapa lokasi di dalam gua sebagai tempat untuk mengatur jarak antar kelompok. Reservasi secara online sebisa mungkin diberlakukan agar jumlah wisatawan dapat dikontrol setiap harinya dan sekaligus menghindari kerumunan di lokasi pembelian tiket (Durán-Valsero et al., 2020). Khusus gua wisata yang menjadi habitat bagi kelelawar, maka kewaspadaan harus lebih ditingkatkan. Sedapat mungkin rute kunjungan dibuat menghindari lorong-lorong dimana populasi kelelawar biasanya berkumpul. Hal ini penting untuk mencegah terjadinya kemungkinan transmisi virus ke kelelawar (Nuñez et al., 2020).

Kunjungan ke gua untuk berburu kelelawar harus dihentikan. Aktivitas ini tidak hanya berpotensi menularkan Covid-19 ke kelelawar akan tetapi juga memungkinkan terjadinya infeksi penyakit baru dari kelelawar ke manusia. Kelelawar merupakan inang alami yang penting bagi virus patogen atau virus yang menyebabkan penyakit pada manusia (Han et al., 2015). Banyak penyakit zoonosis berbahaya dan mematikan disebabkan oleh virus yang awalnya hidup di inang alami kelelawar seperti Nipah, Hendra, Menangle, Rabies, Marburg, Ebola, MERS, dan SARS (Tabel 1) (Ranjan et al., 2016). Para peneliti meyakini bahwa masih terdapat banyak mikroba patogen dari kelelawar yang berpotensi menginfeksi manusia. Oleh karena itu, segala aktivitas yang mengarah ke kontak langsung dengan kelelawar termasuk berburu, memelihara, dan terlebih mengkonsumsi kelelawar harus diminimalisir guna mencegah terjadinya infeksi mikroba patogen. Tabel 1. Virus penyebab penyakit zoonosis yang berasal dari inang alami kelelawar

\begin{tabular}{|c|c|c|c|}
\hline $\begin{array}{l}\text { Nama } \\
\text { Virus }\end{array}$ & Nama Penyakit & $\begin{array}{l}\text { Daerah Asal } \\
\text { Kemunculan }\end{array}$ & Referensi \\
\hline Hendra & $\begin{array}{l}\text { Hendra disease/Fatal respiratory } \\
\text { disease }\end{array}$ & $\begin{array}{l}\text { Queensland, } \\
\text { Australia }\end{array}$ & $\begin{array}{l}\text { Allocati et al., (2016); } \\
\text { Han et al., (2015) }\end{array}$ \\
\hline Nipah & Nipah disease/severe encephalitis & Malaysia & $\begin{array}{l}\text { Allocati et al., (2016); } \\
\text { Han et al., (2015) }\end{array}$ \\
\hline Menangle & $\begin{array}{l}\text { Severe but self-limited influenza- } \\
\text { like disease }\end{array}$ & Australia & Barr et al., (2012) \\
\hline SARS-CoV & Severe acute respiratory syndrome & China & $\begin{array}{l}\text { Han et al., (2015); } \\
\text { Ranjan et al., (2016) }\end{array}$ \\
\hline Rabies & Acute fatal encephalitis & $\begin{array}{l}\text { Afrika, Eropa, } \\
\text { Australia }\end{array}$ & Allocati et al., (2016) \\
\hline Marburg & Marburg hemorrhagic fever & Afrika & Ranjan et al., (2016) \\
\hline Ebola & Ebola hemorrhagic fever & Afrika & Leendertz et al., (2016) \\
\hline $\begin{array}{l}\text { MERS- } \\
\mathrm{CoV}\end{array}$ & Middle East respiratory syndrome & Timur Tengah & Wang et al., (2014) \\
\hline
\end{tabular}

Kegiatan penambangan di gua juga berisiko tinggi dalam penularan Covid-19. Meskipun tidak melibatkan banyak orang seperti halnya wisata gua, akan tetapi para penambang harus berbagi ruang dengan kelelawar penghuni gua dalam waktu yang lama. Salah satu media penularan Covid-19 adalah melalui aerosol atau udara yang terkontaminasi sehingga berbagi udara dengan kelelawar di ruang tertutup sangat berbahaya. Bagi masyarakat yang harus tetap menambang di tengah pandemi, mengenakan masker, sarung tangan, dan pakaian yang menutup 
tubuh serta pelindung kepala semisal helm dapat dilakukan untuk meminimalisir terjadinya paparan (Nuñez et al., 2020). Pelindung diri ini tidak hanya akan mencegah paparan Covid-19, akan tetapi juga infeksi mikroba patogen lainnya seperti Histoplasma capsulatum yang banyak hidup di guano atau kotoran kelelawar (Allocati et al., 2016).

Kegiatan penelusuran oleh pecinta alam dan penggiat caving sebaiknya ditunda sementara waktu hingga situasi membaik. Apabila memutuskan untuk melakukannya, maka pastikan terlebih dahulu bahwa semua anggota tim dalam kondisi sehat dan tidak terpapar atau menunjukkan gejala yang mengarah ke Covid-19. Mayoritas kasus Covid-19 adalah orang tanpa gejala (OTG). Meskipun terlihat sehat, akan tetapi OTG berpotensi menularkan virus (Addi et $a l ., 2020)$. Jangan terburu-buru dalam menjustifikasi aman masuk gua. Penilaian mandiri terlebih dahulu harus dilakukan secara teliti apakah sekitarnya terdapat kemungkinan kita terpapar Covid-19 atau tidak. Apabila keputusan untuk tetap melakukan kunjungan ke gua telah diambil, SOP penelusuran gua dan protokol kesehatan harus dikombinasikan dan dilaksanakan dengan baik dan benar. Hal yang sama juga harus dilakukan oleh para peneliti yang mendesak harus mengunjungi gua untuk dapat memperoleh data.

Rekomendasi khusus bagi para peneliti yang melibatkan kelelawar telah disusun oleh IUCN SSC Bat Specialist Group yaitu dengan slogan KENAL (Kurangi, Nilai, dan Lindungi). (1). Kurangi atau hindari kontak langsung dengan kelelawar dan lebih memanfaatkan metode sampling yang tidak mengharuskan kontak fisik sebagai contoh dengan survei akustik. (2). Nilai diri sendiri apakah ada kemungkinan kita terpapar atau menunjukkan gejala Covid-19. Apabila kemungkinan tersebut ada, maka hindari memegang atau kontak fisik dengan kelelawar. (3). Lakukan tindakan yang dapat mengurangi risiko paparan ketika hendak kontak dengan kelelawar semisal dengan mengenakan pelindung wajah, masker, sarung tangan dan menggunakan disinfektan baik ke tangan maupun semua peralatan penelitian yang kontak dengan kelelawar (Nuñez et al., 2020).

\section{KESIMPULAN}

Gua memiliki kondisi lingkungan tertutup, tidak terdapat sinar matahari, minim sirkulasi udara, dan lembap yang mendukung viabilitas virus SARS-CoV-2 di lingkungan. Gua juga dihuni kelelawar yang berpotensi tertular dan menularkan Covid-19 dari dan ke manusia. Kunjungan ke gua di masa pandemi sangat berbahaya karena dapat memperluas penyebaran virus. Pencegahan penyebaran Covid-19 di lingkungan gua dapat dilakukan di antaranya dengan cara menunda kunjungan ke gua, mengkombinasikan peralatan SOP penelusuran dengan protokol kesehatan, pembatasan jumlah kunjungan dan durasi eksplorasi, tidak kontak langsung dengan kelelawar, dan menghindari lorong-lorong gua yang menjadi habitat kelelawar.

\section{REFERENSI}

Addi, A.R., Benksim, A., Amine, M., and Cherkaoui, M. 2020. Asymptomatic COVID-19 Infection Management: The Key to Stop COVID-19. Journal of Clinical and Experimental Investigations, 11(3): 1-2. https://doi.org/10.5799/jcei/7866 
Kurniawan et al., 2020. Bahaya penularan Covid-19 di Gua....

Allocati, N., Petrucci, A.G., Giovanni, D.P., Masulli, M., Ilio, D.C., and Laurenzi, D.V. 2016. Bat-man disease transmission: zoonotic pathogens from wildlife reservoirs to human populations. Cell Death Discovery, 2: 1-7. https://doi.org/10.1038/cddiscovery.2016.48

Andersen, K.G., Rambaut, A., Lipkin, W.I., Holmes, E.C., and Garry, R.F. 2020. The proximal origin of SARS-CoV-2. Nature Medicine, 26: 450-452. https://doi.org/10.1038/s41591-020-0820-9

Balboni, A., Battilani, M., and Prosperi, S. 2012. The SARS-like coronaviruses: the role of bats and evolutionary relationships with SARS coronavirus. New Microbiologica, 35(1): 1-16.

Barr, J.A., Smith, C., Marsh, G.A., Field, H., and Wang, L.F. 2012. Evidence of bat origin for Menangle virus, a zoonotic paramyxovirus first isolated from diseased pigs. Journal of General Virology, 93: 2590-2594. https://doi.org/10.1099/vir.0.045385-0

Barton, H.A. 2020. Safe and effective disinfection of showcave infrastructure in a time of COVID-19. International Journal of Speleology, 49(2): 137-147. https://doi.org/10.5038/1827-806X.49.2.2332

Chan, K.H., Peiris, J.S.M., Lam, S.Y., Poon, L.L.M., Yuen, K.Y., and Seto, W.H. 2011. The effects of temperature and relative humidity on the viability of the SARS coronavirus. Advances in Virology, 2011: 1-7. https://doi.org/10.1155/2011/734690

Dhama, K., Sharun, K., Tiwari, R., Dadar, M., Malik, Y.S., Singh, K.P., and Chaicumpa, W. 2020. COVID-19, an emerging coronavirus infection: advances and prospects in designing and developing vaccines, immunotherapeutics, and therapeutics. Human Vaccines and Immunotherapeutics, February: 1-7. https://doi.org/10.1080/21645515.2020.1735227

Doremalen, N.V., Bushmaker, T., Morris, D.H., Holbrook, M.G., Gamble,A., Williamson, B.N., ... Munster, V.J. 2020. Aerosol and Surface Stability of SARS-CoV-2 as Compared with SARS-CoV1. The New England Journal of Medicine, 382(16): 1-4. https://doi.org/DOI: 10.1056/NEJMc2004973

Durán-Valsero, J.J., Robledo-Ardila, P.A., and Morales-García, R. 2020. International Show Caves Association (ISCA) Recommendations For Show Caves in Relation to The Sars-Cov-2 Virus Pandemic (Covid-19) (Vol. 2). Retrieved from http://www.i-s-c-a.org/news/221-isca-covidrecommendations

Furey, N.M., and Racey, P.A. 2016. Conservation Ecology of Cave Bats. In C. V. Christian \& T. Kingston (Eds.), Bats in the anthropocene: Conservation of bats in a changing world (1st ed., pp. 463-500). https://doi.org/10.1007/978-3-319-25220-9

Han, H.J., Wen, H.L., Zhou, C.M., Chen, F.F., Luo, L.M., Liu, J.W., and Yu, X.J. 2015. Bats as reservoirs of severe emerging infectious diseases. Virus Research, 205: 1-6. https://doi.org/10.1016/j.virusres.2015.05.006

Helmy, Y.A., Fawzy, M., Elaswad, A., Sobieh, A., Kenney, S.P., and Shehata, A.A. 2020. The COVID19 Pandemic: A Comprehensive Review of Taxonomy, Genetics, Epidemiology, Diagnosis, Treatment, and Control. Journal of Clinical Medicine, 9(4): 1225-1252. https://doi.org/10.3390/jcm9041225

Hobday, R.A., and Dancer, S.J. 2013. Roles of sunlight and natural ventilation for controlling infection: Historical and current perspectives. Journal of Hospital Infection, 84(4): 271-282. https://doi.org/10.1016/j.jhin.2013.04.011

Iyiola, A.O., Asiedu, B., and Fawole, F.J. 2020. Possible effects of COVID-19 on sustainability of aquatic ecosystems: An overview. Aquatic Research, 3(4): 177-187. https://doi.org/10.3153/ar20016

Kim, J.S., Jang, J.H., Kim, J.M., Chung, Y.S., Yoo, C.K., and Han, M.G. 2020. Genome-Wide Identification and Characterization of Point Mutations in the SARS-CoV-2 Genome. Osong Public Health and Research Perspectives, 11(3): 101-111. https://doi.org/10.24171/j.phrp.2020.11.3.05

Kiros, M., Andualem, H., Kiros, T., Hailemichael, W., Getu, S., Geteneh, A., ... Abegaz, W.E. 2020. COVID-19 pandemic: current knowledge about the role of pets and other animals in disease transmission. Virology Journal, 17(1): 1-8. https://doi.org/10.1186/s12985-020-01416-9 
Kumar, O.R.V., Ramkumar, Pruthvishree, B.S., Pande, T., Sinha, D.K., Singh, B.R., ... Malik, Y.S. 2020. SARS-CoV-2 (COVID-19): Zoonotic origin and susceptibility of domestic and wild animals. Journal of Pure and Applied Microbiology, 14(Special Edition): 1-7. https://doi.org/10.22207/JPAM.14.SPL1.11

Kurniawan, I.D., and Rahmadi, C. 2019. Ekologi Gua Wisata. Yogyakarta: Graha Ilmu.

Leendertz, S.A.J., Gogarten, J.F., Düx, A., Calvignac-Spencer, S., and Leendertz, F.H. 2016. Assessing the evidence supporting fruit bats as the primary reservoirs for ebola viruses. EcoHealth, 13(1): 1825. https://doi.org/10.1007/s10393-015-1053-0

Nabi, G., Wang, Y., Hao, Y., Khan, S., Wu, Y., and Li, D. 2020. Massive use of disinfectants against COVID-19 poses potential risks to urban wildlife Coronavirus. Environmental Research, 188(September 2020, 109916): 1-3. https://doi.org/https://doi.org/10.1016/j.envres.2020.109916

Nuñez, G.B., Cunningham, A., Moise, E., Fils, B., Frick, W., Islam, N., ... Dinh, T.V. 2020. IUCN SSC Bat Specialist Group ( BSG) Recommended Strategy for Researchers to Reduce the Risk of Transmission of SARS-CoV-2 from Humans to Bats. Retrieved from https://www.iucnbsg.org/uploads/6/5/0/9/6509077/map_recommendations_for_researchers_v._1.0_f inal.pdf

Oreshkova, N., Moelnaar, R.J., Vreman, S., Harders, F., Munnink, B.B.O., Honin, R.W.H.V.D, ... Stegeman, A. 2020. SARS-CoV-2 infection in farmed minks, the. Euro Surveillance, 25(23): 1-7. https://doi.org/https://doi.org/10.2807/1560-7917.ES.2020.25.23.2001005

ProMed. 2020. Coronavirus disease 2019 update (169): Netherlands (North Brabant) animal, farmed mink, spread, rabbit suspected. Retrieved June 26, 2020, from https://promedmail.org/promedpost/?id=7316646

Ranjan, K., Prasad, M., and Prasad, G. 2016. Bats: carriers of zoonotic viral and emerging infectious diseases. Journal of Experimental Biology and Agricultural Sciences, 4(3S): 291-306. https://doi.org/10.18006/2016.4(3s).291.306

Ratnesar-Shumate, S., Williams, G., Green, B., Krause, M., Holland, B., Wood, S., ... Dabisch, P. 2020. Simulated Sunlight Rapidly Inactivates SARS-CoV-2 on Surfaces. The Journal of Infectious Diseases, 222(2): 1-9. https://doi.org/10.1093/infdis/jiaa274

Shang, J., Wan, Y., Luo, C., Ye, G., Geng, Q., Auerbach, A., and Li, F. 2020. Cell entry mechanisms of SARS-CoV-2. Proceedings of the National Academy of Sciences of the United States of America, 117(21): 11727-11734. https://doi.org/10.1073/pnas.2003138117

Sharun, K., Tiwari, R., Patel, S.K., Karthik, K., Yatoo, M.I, Malik, Y.S., ... Dhama, K. 2020. Coronavirus disease 2019 (COVID-19) in domestic animals and wildlife: advances and prospects in the development of animal models for vaccine and therapeutic research. Human Vaccines and Immunotherapeutics, 2020: 1-12. https://doi.org/10.1080/21645515.2020.1807802

Sun, P., Lu, X., Xu, C., Sun, W., and Pan, B. 2020. Understanding of COVID-19 based on current evidence. Journal of Medical Virology, 92(6): 548-551. https://doi.org/10.1002/jmv.25722

Tang, X., Wu, C., Li, X., Song, Y., Yao, X., Wu, X., ... Lu, J. 2020. On the origin and continuing evolution of SARS-CoV-2. National Science Review, 7(6): 1012-1023. https://doi.org/10.1093/nsr/nwaa036

Tiwari, R., Dhama, K., Sharun, K., Iqbal Yatoo, M., Malik, Y.S., Singh, R., ... Rodriguez-Morales, A.J. 2020. COVID-19: animals, veterinary and zoonotic links. Veterinary Quarterly, 40(1): 169-182. https://doi.org/10.1080/01652176.2020.1766725

Triandini, E., Jayanatha, S., Indrawan, A., Werla Putra, G., and Iswara, B. 2019. Metode Systematic Literature Review untuk Identifikasi Platform dan Metode Pengembangan Sistem Informasi di 
Kurniawan et al., 2020. Bahaya penularan Covid-19 di Gua....

Indonesia. Indonesian Journal of Information Systems, 1(2): 63-77. https://doi.org/10.24002/ijis.v1i2.1916

Tu, Y.F., Chien, C.S., Yarmishyn, A.A., Lin, Y.Y., Luo, Y.H., Lin, Y.T., ... Chiou, S.H. 2020. A review of sars-cov-2 and the ongoing clinical trials. International Journal of Molecular Sciences, 21(7): 2657-2676. https://doi.org/10.3390/ijms21072657

Valitutto, M.T., Aung, O., Tun, K.Y.N., Vodzak, M.E., Zimmerman, D., Yu, J.H., ... Mazet, J. 2020. Detection of novel coronaviruses in bats in Myanmar. PLoS ONE, April 9: 1-11. https://doi.org/10.1371/journal.pone.0230802

Wang, Q., Qi, J., Yuan, Y., Xuan, Y., Han, P., Wan, Y., ... Gao, G.F. 2014. Bat origins of MERS-CoV supported by bat Coronavirus HKU4 usage of human receptor CD26. Cell Host and Microbe, 16(3): 328-337. https://doi.org/10.1016/j.chom.2014.08.009

WHO. 2020. Coronavirus disease 2019 (COVID-19) Situation Report - 94. Retrieved June 30, 2020, from https://www.who.int/docs/default-source/coronaviruse/situation-reports/20200423-sitrep-94covid-19.pdf

Wong, A.C.P., Li, X., Lau, S.K.P., and Woo, P.C.Y. 2019. Global epidemiology of bat coronaviruses. Viruses, 11(2): 1-17. https://doi.org/10.3390/v11020174

Wu, Y., Jing, W., Liu, J., Ma, Q., Yuan, J., Wang, Y., ... Liu, M. 2020. Effects of temperature and humidity on the daily new cases and new deaths of COVID-19 in 166 countries. Science of the Total Environment, 729: 1-7. https://doi.org/10.1016/j.scitotenv.2020.139051

Zhang, D.X. 2020. SARS-CoV-2: air/aerosols and surfaces in laboratory and clinical settings. Journal of Hospital Infection, 105(3): 577-579. https://doi.org/10.1016/j.jhin.2020.05.001

Zhang, H., Tang, W., Chen, Y., and Yin, W. 2020a. Disinfection threatens aquatic ecosystems. Science, 368(6487): 146-147. https://doi.org/10.1126/science.abb8905

Zhang, T., Wu, Q., and Zhang, Z. 2020b. Probable Pangolin Origin of SARS-CoV-2 Associated with the COVID-19 Outbreak. Current Biology, 30(7):1346-1351. https://doi.org/10.1016/j.cub.2020.03.022

Zheng, J. 2020. SARS-CoV-2: an Emerging Coronavirus that Causes a Global Threat. International Journal of Biological Sciences, 16: 1678-1685. https://doi.org/10.7150/ijbs.45053

Zhou, P., Yang, X. Lou, Wang, X.G., Hu, B., Zhang, L., Zhang, W., ... Shi, Z.L. 2020. A pneumonia outbreak associated with a new coronavirus of probable bat origin. Nature, 579(7798): 270-273. https://doi.org/10.1038/s41586-020-2012-7

\section{Authors:}

Isma Dwi Kurniawan, Jurusan Biologi, UIN Sunan Gunung Djati Bandung, Jl. A.H Nasution No.105, Cibiru, Bandung, 40614, Jawa Barat, Indonesia, email: ismadwikurniawan@uinsgd.ac.id

Cahyo Rahmadi, Museum Zoologicum Bogoriense, Lembaga Ilmu Pengetahuan Indonesia (LIPI), Jl. Raya JakartaBogor km 46, Cibinong, Bogor, 16911, Jawa Barat, Indonesia, email: cahyo.rahmadi@gmail.com

Rasyid Wisnuaji, Jurusan Ekonomi Pembangunan, Universitas Nahdlatul Ulama Al-Ghozali, Jl. Kemerdekaan Barat No.17, Gligir, Kesugihan Kidul, Cilacap, 53274, Jawa Tengah, Indonesia, email: rasyid.sig@gmail.com

This is an open-access article distributed under the terms of the Creative Commons Attribution License, which permits unrestricted use, distribution and reproduction in any medium, provided the original author and source are credited. (http://creativecommons.org/licenses/by/4.0/).

\section{How to cite this article:}

Kurniawan, I.D., Rahmadi, C., and Wisnuaji, R. 2020. The pitfall of Covid-19 transmision in caves and its prevention. Simbiosa, 9(2): 166-176. Doi. http://dx.doi.org/10.33373/sim-bio.v9i2.2529 